\title{
Corpus jurídico, operadores e sujeitos de direito nas práticas da lei de terras de 1850
}

Corpus juridicum, legal operators and subjects in agrarian law practices in 1850

Eliana Ramos Ferreira - Doutora em História Social pela PUC-SP, Professora da Escola de Aplicação da Universidade Federal do Pará e membro dos Grupos de Pesquisa: Eneida de Moraes sobre Mulher e Relações de Gênero - GEPEM; Oitocentos: Historia da Amazônia e Usos da Terra na Amazônia Luso-Brasileira. Email: lia@ufpa.br

\section{Resumo}

O presente trabalho pretende refletir sobre o processo de implantação da Lei de Terras de 1850 e do Decreto $n^{\circ} 1318$, de 30 de janeiro de 1854 na Província do Pará, focalizando as relações de tensões e conflitos gerados a partir da decretação da Lei e dos caminhos não raramente tortuosos do processo de sua aplicação, observância e vigilância por parte do Estado e dos sujeitos da lei. Além das formas de apropriação elaboradas por aqueles que se tornaram os sujeitos desse direito, e em seu nome conclamaram por justiça no Pará Provincial.

\section{Palavras-chave}

Lei de Terras. Terras. Pará Provincial. Tensões Burocráticas. Conflito Agrário

\begin{abstract}
The present work intends to reflect on the process of implantation of the Land Law of 1850 and of the Decree $n^{\circ} 1318$, of 30 of January of 1854 in the Province of Pará, focusing the relations of tensions and conflicts generated from the decreement of the Law and the ways not rare tortuous of the process of its application, observance and monitoring by the state and subjects of the law. In addition to the forms of ownership produced by those who have become the subjects of this law, and in its name had convoked for justice in Provincial Pará.
\end{abstract}

\section{Keywords}

Land Law. Land. Para Provincial. Bureaucratic Tensions. Agrarian Conflict 


\title{
INTRODUÇÃO
}

De facto, os produtores de leis, de regras e de regulamentos devem contar sempre
com as reações e, por vezes, com as resistências, de toda a corporação jurídica. Bourdieu $^{1}$

Os efeitos da decretação de uma lei na sociedade seguem percursos diferentes, geralmente, imprevistos aos operadores do direito e aos seus autores. A partir de sua aprovação, do seu registro segue um caminho - não raramente tortuoso - de sua aplicação, observância, vigilância por parte do Estado e dos sujeitos da lei. Em especial, o que é objeto de interpretação, neste capítulo, são as formas e sentidos de apropriação elaborados por aqueles que se tornaram os sujeitos desse direito e em seu nome conclamam por justiça, além das relações de conflito em que ficaram inseridos ${ }^{2}$.

Segundo Fortes (1995), o elemento central da abordagem de Thompson é a distinção de três aspectos diferenciados na lei: a instituição (e aqueles que a exercem, a ideologia e o código com lógica e procedimentos próprios (a lei enquanto leı). E continua

\begin{abstract}
A lei não pode ser localizada apenas nos aparatos jurídico e legislativo, mas aparece como componente intrínseco ao conflito que se caracteriza não como uma luta contra a propriedade (é a lei que a mantém), mas entre definições distintas de propriedade (e, portanto, dentro lei até onde possível e recorrendo a uma noção legitimadora da política quanto estas possibilidades se esgotam), portanto, não se localizam em uma distante superestrutura, mas perpassa as próprias relações de produção como norma endossada pela comunidade. Por outro lado, ao invés de mecanismo de consenso, constituía-se no próprio campo onde o conflito se desenvolva (FORTES, 1995).
\end{abstract}

Estudar a Lei de Terras de 1850 inicia com a estrutura administrativa criada, atribuições, funcionamento e financiamento. Aqui se entende que esse conhecimento faculta compreender o campo de relações sociais entre operadores da lei e os sujeitos da lei (posseiros). Essa relação atribui ao(s) operador(es) uma posição dominante.

A Lei $\mathrm{n}^{\circ}$ 601, de 18 de setembro de 1850, mais conhecida como a Lei de Terras de 1850, aprovada depois de longo debate no parlamento do Império, foi regulamentada pelo Decreto 1.318 , de 30 de janeiro de $1854^{3}$ que buscava

\footnotetext{
BOURDIEU, P., 2006. p. 217.

Proposição inspirada na obra de Thompson (1987).

Decreto 1.318, de 30 de janeiro de 1854. Cf.: BRASIL. Ministério da Agricultura, Pecuária e

Abastecimento. Os debates foram intensos e conflituosos; o projeto foi apresentado ao senado
} 
normalizar a aplicação da Lei, bem como atender às diversas situações existentes quanto à forma de acesso a terra.

Um dos primeiros passos do referido Decreto foi definir a montagem dos mecanismos necessários para a sua execução. Isso implicou no aparelhamento de uma estrutura burocrático-administrativa já prevista na Lei nº 601 de 18 de setembro de 1850, que servisse como instrumento de viabilização das orientações jurídicas contidas no Decreto 1.318, de 30 de janeiro de 1854.

Neste sentido, todo o Capítulo I (com seus nove artigos) do Decreto é voltado para a definição das atribuições e competências da Repartição Geral de Terras Públicas e seu funcionamento, órgão pensado para conduzir o processo de medição e separação das terras devolutas e públicas, das terras privadas, ou seja, que estivessem em mãos de particulares.

A Repartição Geral das Terras Públicas ficou subordinada diretamente ao Ministro e Secretário de Estado dos Negócios do Império, no Rio de Janeiro, que adotava assim uma estrutura centralizada e dependente, reflexo da importância que assumia a regularização fundiária para a nova Nação.

A Repartição estava composta por um oficial maior, dois oficiais, quatro amanuenses, um porteiro e um contínuo, os quais seriam "nomeados por Decreto Imperial, excepto os Amanuenses, Porteiro, e Contínuo, que o serão por Portaria do Ministro e Secretário de Estado dos Negócios do Império; e terão os vencimentos seguintes" (Quadro 1).

Quadro 1. Cargos e Remuneração Mensal da Repartição Geral das Terras Públicas, conforme estabelecido pelo Decreto No 1.318, de 30 de janeiro de 1854.

\begin{tabular}{|l|l|c|}
\hline Diretor Geral & Quatro contos de réis & $4.000 \$ 000$ \\
\hline Fiscal & Dois contos e quatrocentos mil réis & $2.400 \$ 000$ \\
\hline Oficial Maior & Três contos e duzentos mil réis & $3.200 \$ 000$ \\
\hline Oficiais (cada um) & Dois contos e quatrocentos mil réis & $2.400 \$ 000$ \\
\hline Amanuenses (cada um) & Um conto e duzentos mil réis & $1.200 \$ 000$ \\
\hline Porteiro & Um conto de réis & $1.000 \$ 000$ \\
\hline Contínuo & Seiscentos mil réis & $600 \$ 000$ \\
\hline
\end{tabular}

Fonte: BRASIL. Ministério da Agricultura, Pecuária e Abastecimento. Decreto 1.318, de 30 de janeiro de 1854. Capítulo I, Art. $2^{\circ}$.

em outubro de 1843 e aprovado somente em 1850, durante o gabinete conservador, que ficou no governo durante o período de 1848 a 1852 (CARVALHO, 1996. p.303-325). Ver também Motta (1998) e Silva (1996). 
As remunerações estipuladas a esses funcionários eram relativamente significativas em comparação, por exemplo, ao preço de escravos em idade produtiva na cidade de Belém, onde os preços variavam em $150 \$ 000$ a $250 \$ 000$ mil réis.

De acordo com o Art. 60, haveria "nas Províncias huma Repartição Especial das Terras Publicas nellas existentes". Esta Repartição estava subordinada aos Presidentes das Províncias, e dirigida por:

[...] hum Delegado do Director Geral das Terras Publicas, hum Fiscal, que será o mesmo da Thesouraria; os Officiaes e Amanuenses, que forem necessários, segunda a affluencia do trabalho, hum Porteiro servindo de Archivista. ${ }^{4}$

O Delegado e os oficiais seriam nomeados por Decreto Imperial, enquanto que os amanuenses e o porteiro por portaria do ministro e secretário de estado dos Negócios do Império. A montagem dessa organização burocrática exigiu uma mobilização de recursos do estado.

Em relatório do ano de 1855, o ministro dos Negócios do Império, Luiz Pedreira do Coutto Ferraz, apresentou um cômputo das "Despesas com as Repartições Especiais creadas nas províncias" e que foram 13 (treze), totalizando $81.660 \$ 000$ (oitenta e um conto, seiscentos e sessenta mil réis) e, destes, 5.520\$000 (cinco contos, quinhentos e vinte mil réis), foram consumidos no estabelecimento da Repartição Especial das Terras Públicas da Província do Pará (BRASIL, 1855). Desta forma, os dados financeiros oficiais destinados ao projeto de estruturação da Repartição Geral das Terras Públicas revelam a envergadura da intencionalidade do Estado em efetivar o Decreto de janeiro de $1854^{5}$.

No montante dos recursos alocados para o Pará, estavam incluídas as despesas com o vencimento do delegado da repartição, a gratificação do fiscal, vencimento do oficial, do amanuense, do porteiro, além do aluguel da casa que abrigava a repartição e outras despesas consideradas miúdas, e que, portanto, não foram especificadas, conforme disposição da Tabela 1.

Estes cargos das repartições especiais das terras públicas seriam ocupados por pessoas nomeadas pelo presidente das respectivas províncias. Tratava-se de cargos de confiança, revelando laços políticos.

Os nexos hierárquicos entre esses cargos e seus vínculos políticos identificam-se a partir do organograma apresentado a seguir (Figura 1).

\footnotetext{
Id. Ibid.

5 O outro lado dessa moeda, eram os projetos de colonização que tiveram a previsão orçamentária de 306.926\$482. Ibidem.
} 
Tabela 1. Despesas com as repartições especiais creadas nas Províncias.

\begin{tabular}{lcc}
\hline \multicolumn{1}{c}{ Cargo } & Tipo de remuneração & Valor (\$Réis) \\
\hline Delegado & Vencimento & $1.600 \$ 000$ \\
Fiscal & Gratificação & $300 \$ 000$ \\
Official & Vencimento & $1.200 \$ 000$ \\
Amanuense & Idem & $600 \$ 000$ \\
Porteiro & Idem & $800 \$ 000$ \\
Total Parcial & $* * * * * * * * * * * * * * * *$ & $4.500 \$ 000$ \\
Aluguel de casa & & $600 \$ 000$ \\
Expediente & & $300 \$ 000$ \\
Despezas miúdas & & $120 \$ 000$ \\
\hline Total & & $5.520 \$ 000$ \\
\hline
\end{tabular}

Fonte: BRASIL. Ministério do Império. Relatório do Anno de 1855.

Conforme esse organograma, o presidente da Província e a Repartição Geral das Terras constituíam duas instâncias paralelas. A primeira, como instância de decisão e informação composta pelos juízes (de direito, municipal, de paz), que remeteriam informações sobre os termos de posse e sesmarias a serem legitimadas. A segunda, como instância de execução de medições e com colaboração de uma instância religiosa.

No presente trabalho, entende-se que estes se constituem tanto em esferas administrativas quanto de poder. A questão central é reconhecer as instâncias de poder e sua hierarquia.

Ligia Osório Silva (1996) refere-se que são os três braços do regulamento de 1854: o provincial, o central e o registro do vigário. Neste organograma ${ }^{6}$, depreende-se que havia três vertentes de articulações administrativas e políticas: a central, o Ministério dos Negócios do Império, centro administrativo que ficava no Rio de Janeiro, representado pela Repartição das Terras Públicas, vinculada a ele e cujos funcionários seriam nomeados por decreto imperial. A provincial, representada pelos presidentes das províncias, com grande penetrabilidade político regional, teria influência na otimização dos trabalhos de mapeamento fundiário do país; era encarregada pelas nomeações dos agentes executores das diretrizes do Decreto de 1854, tanto dos responsáveis pelos aspectos jurídico e policial,

6 Para o organograma administrativo responsável pela política indígena, ver Sampaio (2007). 
como os juízes e delegados; quanto dos agentes de campo, como os agrimensores e desenhadores responsáveis pelos trabalhos de medição e demarcação das terras públicas e privadas. Estes últimos cargos, os de agrimensores e desenhadores exigiam critérios técnicos pertinentes à sua formação.

A terceira vertente é a dos Vigários, responsáveis pelos registros das terras ocupadas em suas paróquias. Essa instância com atuação mais local, mais direta com os paroquianos, possui uma interioridade de poder e, por outro lado, em tese não responderiam aos presidentes de províncias e nem às assembleias legislativas provinciais, mas estavam inseridos no corpo burocrático e administrativo do império via o padroado - todavia, como veremos mais adiante, muitos vigários foram colocados em xeque administrativamente pelos presidentes provinciais, por meio de ofícios e até mesmo da imprensa.

Figura 1. Organograma sobre jurisdição e competências na aplicação da Lei de Terras de 1850, conforme a regulamentação de 1854 .

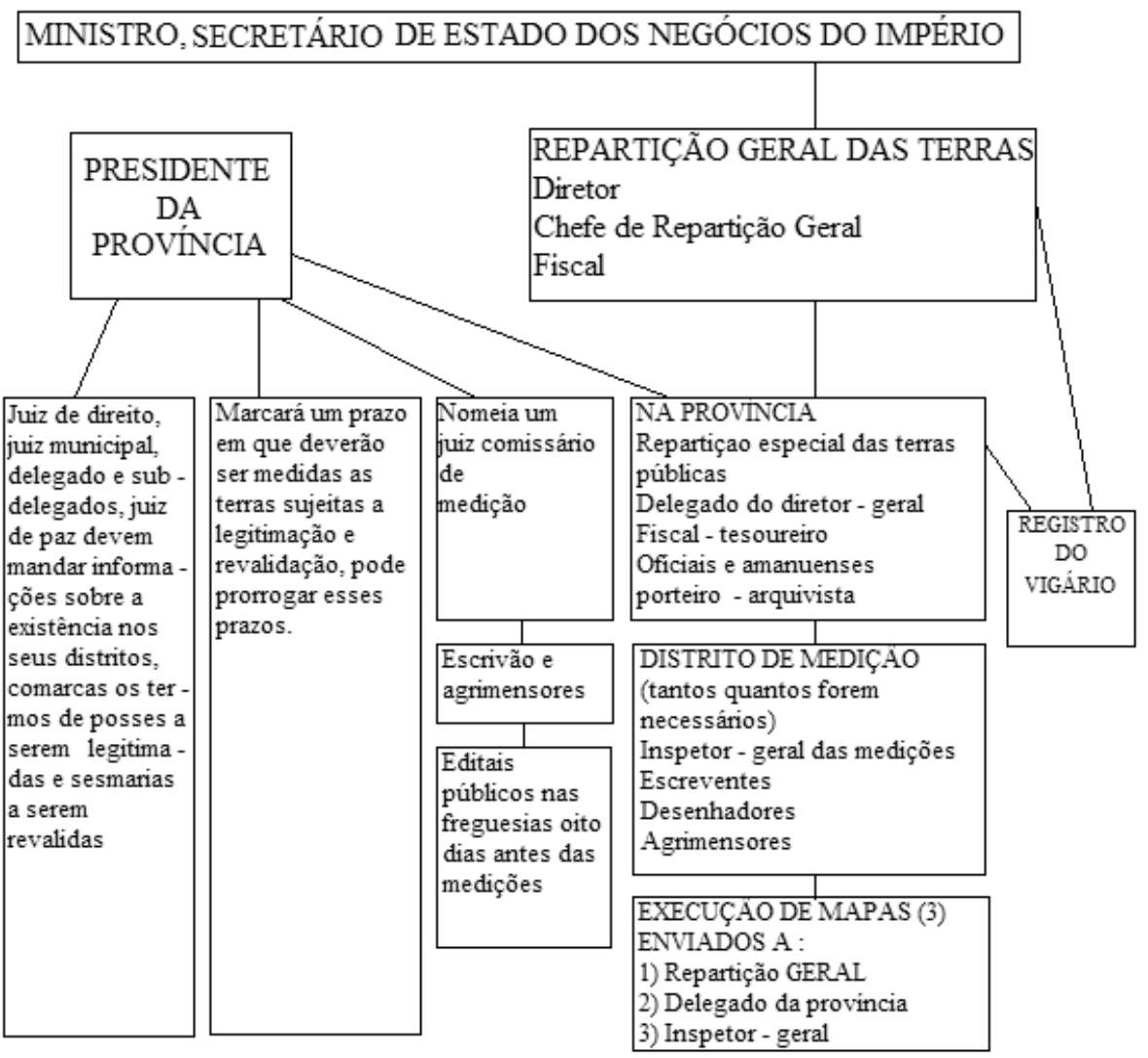

Fonte: Silva (1996. p.178-179). 
Essa mobilização de recursos humanos e financeiros feita pelo estado imperial, mencionadas anteriormente, pode denotar uma possível expectativa de agilização dos serviços da repartição geral das terras públicas para solucionar os problemas fundiários do país. Contudo, para isso, era necessário que as repartições especiais das terras públicas funcionassem de forma célere, para promoverem, o quanto antes, o levantamento e separação das terras públicas, das privadas. Entretanto, vários foram os obstáculos enfrentados, conforme se depreende da visão oficial dos relatórios das autoridades provinciais e do Ministro, Secretário dos Negócios do Império.

Os primeiros estiveram ligados ao reduzido corpo burocrático, designado para conduzir os trabalhos da Repartição. Mesmo com salários tentadores, uma das dificuldades que se apresentaram coevamente à implementação do órgão responsável em dirigir a medição, demarcação, venda, distribuição e conservação das terras públicas, além da discriminação das terras públicas e das particulares, do registro dos terrenos possuídos e colonizados foi a carência de pessoal habilitado para desempenhar as referidas funções da recém-criada Repartição.

Em relatório do ano de 1855, da Repartição Geral das Terras Públicas, apresentado ao ministro Luiz Pedreira do Coutto Ferraz e que compôs o relatório anual ministerial do mesmo ano, o Diretor Manuel Felizardo de Souza e Mello iniciou informando as mudanças ocorridas no corpo administrativo, devido às nomeações de funcionários para outros cargos, logo na primeira linha afirmou que "O pequeno pessoal d'esta Repartição soffreu alteração [...]" (BRASIL, 1856), número reduzido de colaboradores e assoberbado de serviço. Mesmo os amanuenses adquirindo experiência nas novas funções no transcurso de um ano," ainda assim preciso se tornará augmentar o seu numero" (Ibidem., p. 2-3.).

As tarefas de instituição da Lei e a sua aplicabilidade eram de grande envergadura, sem dúvida, pelo balanço feito no referido relatório, releva-se que o aparelhamento de recursos humanos era insipiente para o senhor Manuel Felizardo de Souza Mello, que inicia por enumerar as atividades inerentes aos funcionários da Repartição, assim listados:

A correspondência para a Europa, as multiplicadas informações e Avisos sobre propostas de Colonisação, organisação de instrucções para colônias militares, expedientes com ellas, com as Presidências das Províncias, Delegados e Inspectores Geraes, vão tornando extremamente pesado o serviço e em pouco tempo o pessoal com que a Secretaria foi creada não será sufficiente (BRASIL, 1856, op cit.). 
Em Relatório Ministerial de 1856, o diretor da Repartição Geral das Terras Públicas, Manuel Felizardo de Souza Mello, expõe o cotidiano de seus subordinados, destacando o volume de trabalho e os diversos tipos de encaminhamentos burocráticos que teriam de fazer diariamente com os diversos agentes e instituições do governo, revelando o alcance da nati-rede burocrática e as relações políticas advindas dos trâmites por ele enfatizados, como as ligações internacionais com a Europa, destacando, entre outros negócios, particularmente, o objetivo do projeto governamental de colonização.

Esta Repartição foi pensada, para desempenhar um papel importante na estrutura organizacional política do Estado imperial por ser imbuída da responsabilidade de conduzir o processo político da problemática da terra no país, todavia, contava com um parco contingente humano. Essa ausência de funcionários representaria uma estratégia para se deixar a situação agrária sem solução?

Os burocratas formavam (e formam ainda hoje) uma adaptação às mudanças e, por outro lado, eram detentores de um poder que se fundamentava no domínio da escrita, no poder da pena que lhes conferia lugar social no aparelho burocrático do Estado (RAMA,1985).

A deficiência de pessoal, especializado ou não, persistiu durante o período de instituição e aplicabilidade do Decreto no 1318, de 30 de janeiro de 1854.

A segunda ordem de dificuldade identificada no processo de organização da estrutura da Repartição das Terras Públicas foi a demora na implementação desses órgãos. Eles foram instalados de forma gradual, em ritmos diferenciados nas províncias, em prazo de até um ano ou mais, após a aprovação do Decreto de criação, e neste lapso de tempo, deveriam concluir a organização e proceder a instalação. A dinâmica de instituição desses órgãos nas províncias já revelava que a situação fundiária representava uma questão extremamente delicada e que contaria não apenas com a obstrução política dos fazendeiros para o "possível fracasso" da lei de $1850^{7}$.

Nas Províncias ao Norte do Império, pode-se constatar a dissonância na organização da repartição especial das terras públicas. Em exposição feita ao seu vice-presidente, Manoel Gomes Correa de Miranda, o presidente do Amazonas, conselheiro Herculano Ferreira Penna, informa que

\footnotetext{
7 A tese do fracasso da Lei de Terras de 1850 é defendida por parte da historiografia que se debruça sobre o estudo da história fundiária do país. Entre esses, temos Carvalho (1996. p.303325). Ver também Motta (1998) e Silva (1996).
} 
Logo que recebi o Regulamento N$^{\circ} 1318$ de 30 de Janeiro de 1854, expedido pelo Ministério do Império para execução da Lei № 601 de 18 de Setembro de 1850 fiz dar-lhe toda a publicidade possível, e em 29 de Maio transmitti-o com uma ordem circular às competentes Autoridades, recommendando a sua fiel observancia, e exigindo das indicadas no Art. 28 que me enviassem até o fim de Dezembro as informações de que trata o mencionado Artigo (AMAZONAS, 1855).

O Art. 28 do Decreto $n^{\circ}$ 1.318, de 30 de janeiro de 1854, mencionado por Ferreira Penna, instruía sobre como os presidentes de província precisariam proceder para a execução da referida Lei. Deveriam exigir dos juízes de direito, dos juízes municipais, delegados, subdelegados e juízes de paz informações circunstanciadas sobre a existência ou não em suas comarcas, termos e distritos, de posse sujeitas à legitimação e de sesmarias ${ }^{8}$ ou outras concessões do governo geral ou provincial sujeitas de revalidação. Nesse sentido, é possível deduzir que a aplicação da lei tinha como pré-condição a qualidade da informação. A intencionalidade da lei é uma coisa; outra, é a sua operacionalidade.

A despeito dos esforços aparentemente envidados, a Repartição Especial das Terras Públicas não havia sido instituída, efetivamente, em todas as províncias do império.

O vice-presidente da província do Maranhão, senhor José Joaquim Teixeira Vieira Berford, em relatório de 21 de dezembro de 1855, informa ao presidente da província, comendador Antonio Candido da Cruz Machado, que "Acha-se definitivamente montada esta repartição, graças aos esforços e à dedicação de seu chefe, o doutor João Pedro Dias Vieira"”.

Enquanto isso, na província do Grão-Pará, o presidente Sebastião do Rego Barros, informava em exposição de 14 de maio de 1855 que

A execução da [...] Lei e Regulamento das Terras Publicas começa a effeictuar-se nesta extensíssima Província. [...]. A Repartição não se acha ainda completamente montada na Capital, e não tem podido por ora funccionar, visto como isso suppoem a confecção de trabalhos preliminares [...]. Nestas circunstancias prover desde já todos os lugares d'aquella Repartição que se achão creados, seria sobrecarregar o Estado com uma despeza inútil (PARÁ, 1855. p. 21).

8 As sesmarias, por exemplo, eram objeto de dois registros: as concedidas e confirmadas. Este registro era realizado junto à Corte. No Pará as sesmarias encontram-se no Livro das Sesmarias. João de Palma Muniz elaborou o Catálogo de Sesmarias. Sobre essas informações existem questões sobre justaposição em áreas de competências de duas províncias.

9 O senhor João Pedro Dias Vieira foi, imediatamente à implantação da repartição especial das terras públicas no Maranhão, nomeado pelo imperador para presidir a província do Amazonas. In: MARANHÃO, Governo da província do. Relatorio com que o vice presidente Jose Joaquim Texeira Vieira Berford, entregou a presidência da Província do Maranhão. O Illm. E Exmº Snr. Commendador Antonio Candido da Cruz Machado. 
Os trabalhos preliminares, a que se refere o presidente, seriam as medições dos terrenos que deveriam ser feitas pelos agrimensores. Por outro lado, estas atividades também estavam atrasadas, devido a outros motivos, "de não haverem agrimensores suficientes" (PARÁ, 1856, p. 24-25). E dos dois agrimensores existentes, um foi demitido e o outro adoeceu, impossibilitando-o de dar continuidade aos trabalhos (Ibidem). Outro argumento apresentado pelo presidente Rego Barros, para justificar o atraso nos trabalhos de medição e demarcação, estava ligado às condições climáticas, ou seja, ao rigoroso período de inverno no Pará. Se por um lado, no seu discurso demonstra aparentemente zelo extremado pelas finanças da província, por outro, concorre para o retardamento do processo de demarcação das terras públicas e particulares na província, contrariando as orientações de brevidade emanada da Corte.

Em Aviso de 26 de fevereiro de $1855^{10}$, Luiz Pedreira do Coutto Ferraz, ministro dos Negócios do Império, escreveu ao presidente do Pará, conselheiro Sebastião do Rego Barros cobrando o fato de não ter sido enviado, apesar da solicitação feita pelo governo imperial, em fevereiro de 1854, as informações acerca da existência de sesmarias ou outras concessões e posses dos governos geral e provincial, que estivessem em circunstâncias de serem revalidadas. Isto significa que, exatamente um ano depois, o governo imperial desejava saber os primeiros resultados dos trabalhos das repartições especiais das terras públicas no Pará.

Mas, de acordo com a exposição de 14 de maio de 1855, do presidente Rego Barros à Assembleia Legislativa do Pará, ainda não havia sido instalada a referida Repartição.

A inferência imediata é uma desorganização entre essas duas esferas administrativas do estado (imperial e provincial), responsáveis pela condução dos trabalhos de organização da situação de anomia fundiária. Entretanto, se o governo provincial ainda não havia executado integralmente as orientações de implantação da repartição especial das terras públicas, o executivo paraense não estava de todo parado, pois tal atitude representaria uma afronta explícita ao governo imperial.

Os vigários já haviam começado a fazer os registros paroquiais em suas freguesias, ou como também ficou conhecido, o "registro do vigário". Como apontamos antes, esta era uma das três vertentes político-administrativas do regulamento de 1854; as outras duas seriam a provincial e a central (SILVA, 1996.

10 Arquivo Público do Pará. Fundo: Repartição de Obras Públicas. Série Ofícios (Avisos) da Repartição Geral das Terras Públicas, 1855-1857. v. 6. 
p.167-186). É fato que os registros paroquiais desempenharam papel fundamental para a execução do decreto e da lei de 1850.

Se já havia um descompasso entre as esferas imperial e a provincial, com a presença dos clérigos identifica-se uma rede de conflitos administrativos e (des) caminhos burocráticos que se cruzavam tanto vertical quanto horizontalmente, envolvendo diversos sujeitos: presidentes de província, vigários, fregueses, funcionários da repartição das terras públicas. Esses conflitos acabaram dificultando a otimização dos trabalhos, refletindo na organização da burocracia encarregada de implementar a lei de 1854. As razões são diversas e uma das mais indicadas é a atuação dos vigários.

\section{OS VIGÁRIOS E OS REGISTROS PAROQUIAIS: TENSÕES BUROCRÁTICAS E POLÍTICAS}

O Decreto Imperial de 1.318, de 30 de janeiro de 1854, foi o instrumento jurídico que regulamentou a Lei de Terras de 1850, pretendendo dotar-lhe dos mecanismos necessários à sua execução. Um desses mecanismos foi o Registro Paroquial de Terras, que a rigor não conferia o título de propriedade aos que fizessem a declaração de suas posses. Um dos objetivos era o de contribuir para a reorganização da estrutura fundiária, mediante a discriminação das terras públicas das terras privadas no território nacional.

No entanto, se tinha pouco efeito prático, constituiu-se num instrumento de poder "na decisão acerca do domínio sobre as terras em cada localidade" (MOT'TA, 1998, p. 167).

O ministro Luiz Pedreira do Coutto Ferraz, em relatório do ano de 1856, afirmava junto à Assembleia Geral Legislativa, na $1^{\text {a }}$ sessão, no Rio de Janeiro, que

O registro das terras possuídas se faz com extrema morosidade na maioria das Províncias do Império [...] Também se encaminhará mais aceleradamente para seu resultado, à medida que as explicações [...] forem sendo bem comprehendidas pelos vigários e pelos possuídos (BRASIL. Ministério do Império, 1857).

O comentário do ministro Luiz Coutto é revelador de um dos pontos de tensão no desenvolvimento dos trabalhos de registros de terras possuídas no país. O papel dos vigários e o seu desempenho nesta tarefa estiveram permeados de conflitos e embates entre a organização administrativa laica do estado imperial e 
a compreensão que alguns vigários tinham de que sua missão religiosa "os inibia na realização desta tarefa" "Também é revelador, no sentido de que dentro da engrenagem executiva do estado imperial, havia divergências sérias, pois um dos braços (SILVA, 1996, p.167-86) mais longo do Decreto de 1854, uma parcela dos vigários, segundo opinava o ministro Coutto Ferraz, não estava de todo convencido da importância e necessidade da própria lei, fazendo coro às desconfianças do segmento alvo: os possuidores de terras.

Quanto à morosidade dos registros de terras nas províncias, Motta aponta nos relatórios presidenciais do Rio de Janeiro a permanência de reclamações quanto ao ritmo desse trabalho. Neste mesmo ano, 1856, o presidente do Pará, senhor Sebastião do Rego Barros, também expunha a demora das medições de terras na província, relacionando-a à política de imigração proposta pelo governo central. A oferta de terras públicas para imigrantes dependia do reconhecimento de áreas disponíveis. Dessa forma, a lentidão nos trabalhos de demarcação das terras dificultava a vinda dos colonos para a província.

É muito difícil separar a Lei de Terras do problema da imigração e escravidão. Trata-se de posicionamentos e decisões políticas conexas, que integravam o projeto macro do governo imperial para tentar solucionar um dos problemas basilares que era a substituição da mão de obra escrava pelo trabalho livre, quer dizer, da própria organização do trabalho, o qual rascunhava um quadro de mudanças estruturais que se apresentava na organização da produção, bem como em outros níveis da estrutura social no império. Por esse motivo, exigia medidas e decisões políticas objetivando uma solução compatível. Neste sentido, uma das vias defendida por significativa parcela do Estado Imperial, afinadas com as ideias liberais, foi o desenvolvimento de uma política abolicionista imigrantista, com o estímulo a projetos de colonização, visando à entrada massiva de imigrantes, preferencialmente europeus. Para a execução dessas diretrizes, era necessária a disponibilização de terras aos colonos, e o Estado Imperial precisava mapear as terras que possuía para semelhante fim. Apesar do nexo existente entre abolição do tráfico negreiro, imigração/colonização e a Lei de Terras, resulta perigo limitá-la apenas a essas questões, pois a problemática da terra impõe-se desde o passado colonial recente do império (TRINDADE, 1986, p.139-156).

A pressão governamental sobre os vigários no Pará, para agilizar os trabalhos de registros das terras particulares, pode ser palmilhada, notadamente

11 Ver: Carvalho (1996, p. 303-325) e Motta (1998, p. 159-187). 
em documentos como os requerimentos enviados ao presidente da província e à imprensa.

Durante todo o ano de 1856, no jornal Treze de Maio, encontra-se, geralmente na sessão Expediente do Governo, a publicação de avisos gerais dirigidos aos vigários de diversas freguesias. Ao vigário de Benfica apelava-se para que fosse "quanto antes concluído o registro das terras d'aquella Freguesia, remetendo o respectivo livro ao Delegado do Director Geral das Terras Públicas nesta Capital"12.

Contudo, essa relação hierárquica nem sempre era harmoniosa; tensões existiam e se manifestavam entre representantes dessas duas esferas: governo provincial e eclesiástico (vigários); também emergiam nas páginas do referido periódico, contrapondo hierarquias, autoridades e poder.

O ofício publicado no mesmo jornal, destinado ao vigário de Alenquer era categórico quanto à obediência às ordens,

[...] dizendo-lhe, em resposta ao seu officio de 18 de Dezembro findo, que não lhe compete conhecer dos motivos que teve a presidência para exigir a remessa do Livro ao Delegado da Repartição das Terras Públicas logo que elle estiver acabado. (grifo nosso) ${ }^{13}$

No Treze de Maio não se encontrou o ofício mencionado do vigário de Alenquer, mas no contrapelo do teor da resposta do presidente ao ofício mencionado, revela-se o choque entre o dirigente da província e os agentes burocráticos fundamentais pelo registro das terras dos particulares.

Pelas entrelinhas do ofício publicado, apreende-se que o presidente achou que a sua autoridade foi colocada em cheque e a hierarquia político-administrativa questionada pelo vigário, já que na resposta veiculada na imprensa enfatizou que não competia ao vigário conhecer os motivos que levou a presidência da província a exigir o envio do Livro do Delegado. Este era o objeto da distensão entre ambos, pois, continha informações que deviam ficar centralizadas, organizadas dentro de um padrão, o que supostamente evitaria irregularidades, adulterações do seu conteúdo e certamente evitaria situações de conflitos entre os interessados ou amostra do exercício de autoridade excessiva por parte dos vigários.

12 Jornal Treze de Maio, n.631. Belém, 8 de janeiro de 1856. p.2. Neste jornal foram encontradas diversas noticias com teor semelhante referentes à Alenquer, Prainha, São Miguel de Beja, Santa Thereza de Curuçá, Bragança. Palma Muniz notícia que havia na Secretaria de Obras Públicas Terras e Viação, cerca de 78 volumes manuscritos. Hoje esses registros paroquiais encontram-se no Instituto de Terras do Pará (ITERPA).

13 Jornal Treze de Maio. Op cit. 
Mas as cobranças sobre os vigários, para que agilizassem o processo de registro das terras em suas paróquias, aconteceram praticamente em toda a província, notadamente após Circular do dia $1^{\circ}$ de setembro de 1855 , oriunda do Ministério dos Negócios do Império para o presidente da província, orientando o governo para que exigisse dos vigários as informações devidas acerca do andamento do registro das terras possuídas, para que fossem remetidas à Repartição Geral das Terras Públicas ${ }^{14}$.

Tal circular foi encaminhada pelo presidente a todos os vigários no dia 6 de outubro de 1855. As tensões políticas entre as três vertentes (central, provincial e os vigários) se intensificaram depois desse fato. Pressão política do governo central no Rio de Janeiro sobre os presidentes de províncias, e destes sobre os vigários, num efeito cascata, motivou o crescimento considerável da coerção política por parte do governo provincial sobre os vigários, a qual pode ser rastreada por meio do cruzamento de fontes, num jogo de espelhos, pois se encontrou vestígios tanto nas notícias veiculadas no jornal Treze de Maio quanto em ofícios da diretoria geral das terras públicas, revelando uma geografia das tensões entre esses dois poderes.

No dia 14 de janeiro de 1856, foi publicado, no Jornal Treze de Maio, o aviso destinado ao vigário de Santa Thereza de Curuçá, em Cametá, que devia

Dar as necessárias providencias para que [fosse] feito quanto antes o registros das terras d'aquella Freguesia, remettendo, depois de concluído, o respectivo livro ao Delegado do Director Geral nesta Capital, e à presidência á relação d'aquelles que deixarem de fazer as suas declarações dentro do primeiro praso, a fim de lhes ser imposta a multa a que estão sujeitos na forma do Regulamento $\mathrm{n}^{\circ} 1.318$ de 30 de Janeiro de $1854 .^{15}$

No dia 31 de janeiro de 1856, o mesmo jornal publicou aviso, desta vez, para o vigário da Freguesia das Salinas, alertando-o também para

Que com toda a brevidade trate de completar o registro das Terras da sua Freguesia, e remetta o respectivo livro ao Delegado do Director Geral das Terras Públicas, segundo lhe foi recommendado pela presidência. ${ }^{16}$

Em 7 de fevereiro de 1856, o mesmo jornal noticiou outro aviso, mas dessa vez o alvo era o vigário da freguesia de Soure, município da região do Marajó, solicitando que

\footnotetext{
14 Arquivo Público do Pará. Fundo: Repartição de Obras Públicas. Séries: Ofícios (Avisos) da Repartição Geral das Terras Públicas, 1855-1857, v. 9.

15 Jornal Treze de Maio, n.636. Belém, 14 de janeiro de 1856. p. 2.

16 Jornal Treze de Maio, n.651. Belém, 31 de janeiro de 1856. p.2.
} 
[...] se esforce para que com toda a brevidade seja concluído, o respectivo Registro das Terras d'aquella Freguesia, remettendo, depois de concluído, o respectivo livro ao Delegado do Director d'aquella Repartição, na forma das ordens que anteriormente lhe forão expedidas. ${ }^{17}$

A tensão aumentava entre os agentes civis do governo e os vigários quando os trabalhos de registrar as terras possuídas enfrentavam reveses, contribuindo ainda mais para a denominada morosidade nos registros paroquiais. Um desses reveses relacionava-se com o aspecto formal dos Registros Paroquiais, expresso no Art. 100 do Decreto 1.318, que explicitava os dados que as declarações das terras possuídas deviam conter: "o nome do possuidor; a designação da Freguezia, em que estão situadas; o nome particular da situação (se o tiver); sua extensão (se for conhecida) e seus limites"18.

Os vigários teriam que destinar um livro para esta finalidade, devidamente numerado rubricado, aberto e por eles encerrado, nos quais deveriam considerar as declarações apresentadas pelos paroquianos. Esses aspectos formais deveriam ser observados, pois eram os dados que interessavam ao governo imperial, principalmente, a extensão, o limite e a forma de acesso à terra. No entanto, alguns vigários desconsideravam essa norma. A motivação da desconsideração fica em aberto, poderia ser somente engano, como saber?

O Aviso publicado em 9 de janeiro de 1856, no periódico Treze de Maio, destinado ao vigário do Acará, comunicava-lhe que o Livro do Registro das Terras, que remeteu ao Delegado da Repartição, seria devolvido

Por quanto o que se exigio foi que o dito Livro fosse remettido com registro feito, e não da maneira por que o fez, muito principalmente deixando de vir acompanhado da respectiva relação, devendo por tanto tratar de concluil-o quanto antes e enviar à Presidência logo que esteja prompto. Officiou se ao Delegado da Repartição das Terras para devolver-lhe o sobre-dito Livro. ${ }^{19}$

As orientações para o seu preenchimento estavam dadas e deveriam ser seguidas e não podiam ser ignoradas ou desviadas pelos agentes clericais sob o risco de concorrer para a lentidão do processo. Pelo menos, este era o entendimento da ordem imperial que procurou disciplinar essa incumbência dos párocos ao estabelecer, no Art. 105 do Decreto 1.318, a multa de cinquenta a duzentos mil réis, se "extraviarem alguma das declarações, não fizerem o registro ou nelle

\footnotetext{
17 Jornal Treze de Maio, n.656. Belém, 7 de fevereiro de 1856. p.2.

18 Decreto $N^{o} 1.318$, de 30 de Janeiro de 1854. Disponível em: < http:/ / extranet.agricultura.gov. $\mathrm{br} /$ sislegis-consulta $/$ consultarLegislacao. do? operacao $=$ visualizar\&id $=10515>$.

19 Jornal Treze de Maio, n.632. Belém, 9 de janeiro de 1856. p.1.
} 
commetterem erros" ${ }^{20}$. Insistia-se na conclusão do registro o mais breve possível e o reenvio do livro para a presidência da província ${ }^{21}$.

Em Ofício de agosto de 1858, o Vigário de Melgaço informava à secretaria do governo que os livros de registros paroquiais solicitados haviam sido enviados pelo Vigário de Breves, pois nesse tempo Melgaço havia passado de Vila à Capela Filial, sujeita a Breves, formando então uma só Paróquia. Diz ser tudo o que podia informar.

Outra frente de tensão entre as esferas central e paroquial era pertinente ao envio das relações dos multados. Para o ministro Sergio Teixeira de Macedo, havia "grande relutância por parte dos vigários em fornecer as relações dos multados por falta de registro, tendo apenas 12 feito este dever". Também destacava a falta de uniformidade e até "irregularidades encontradas nos livros" 22

Ora, a uniformidade e padronização das informações era uma necessidade do estado, tanto que o ministro Sergio Teixeira de Macedo pretendia "formular um modelo que servisse de norma para as novas informações [...] e uniformizando-as com aquellas que forem sendo ministradas à vista do referido modelo, classificadas por comarcas, municípios e freguezias"23.

Essas idas e vindas do trâmite burocrático revelam as dificuldades e as tensões políticas para a implantação do Decreto 1318.

A posição dos vigários era geralmente ambígua (CARVALHO, 1996, p.155-180), pois sendo membro da burocracia profissional do estado, também representava um agente eclesiástico responsável pela saúde espiritual dos fiéis e, em casos não raros, eles também eram proprietários de terras. Esses três planos de atuação dos vigários, e desde os quais agiram, instigam a investigação histórica, a propósito de conflituosidade na trajetória de aplicação da lei, dos seus logros, morosidade, atraso, inoperância.

Aqui, argumenta-se que antes de aceitar ou reiterar o "fracasso" (ALMEIDA, 2008, p.65-66) ${ }^{24}$ da lei de terras de 1850, é necessário compreender o campo de

20 Decreto $\mathrm{N}^{\circ}$ 1.318, de 30 de Janeiro de 1854. Disponível em: <http://extranet.agricultura.gov. $\mathrm{br} /$ sislegis-consulta $/$ consultarLegislacao.do?operacao $=$ visualizar\&id $=10515>$.

21 Arquivo Público do Pará. Fundo: Obras Públicas. Série: Diretoria Geral das Terras Públicas. n. $20,1858$.

22 BRASIL. Ministério do Império. Ministro Sergio Teixeira de Macedo. Relatório do Anno de 1858 apresentado a Assemblea Geral Legislativa na $3^{a}$ Sessão da $10^{a}$ Legislatura. Publicado em 1959.

23 Ibidem, p.13.

24 Alfredo W. Berno de Almeida propõe a reflexão sobre a também consagrada decadência da lavoura na província do Maranhão como "um padrão de explicação". Para ele, "As interpretações da chamada decadência da lavoura, enquanto um lugar estratégico nas versões oficiais, parecem 
sua aplicação, das diversas intervenções e agentes envolvidos, entre eles a atuação dos vigários, em pelo menos $57^{25}$ das 64 freguesias existentes na província do Pará, no ano de 1859. A partir desta base documental, descortinaram-se situações, possivelmente, comuns a outras unidades político-administrativas do império.

O percurso tortuoso, na perspectiva do trâmite burocrático, dos livros de registros exemplificado com os vigários de Acará e Soure, que fizeram o Livro dos Registros Paroquiais fora do padrão exigido pela Repartição Geral das Terras Públicas, e o de Alenquer, que teria questionado a ordem de envio do dito Livro de Registro ao Presidente da Província, foram censurados publicamente pela imprensa, revelando as dificuldades surgidas de quando a aplicação de normas que também eram recentes e, por conseguinte poderiam ocasionar alguns embaraços e/ou dar margem para as ações contestatórias engendradas nas fímbrias do processo. Esses registros revelam momentos do desempenho dos vigários enquanto agentes burocráticos da ordem imperial e as tensões políticas e burocráticas vividas pelos sujeitos e que perpassaram a viabilização dos registros de terras na província do Pará.

\section{EM CUMPRIMENTO AO EDITAL DO REVERENDO VIGÁRIO}

O presidente Frias e Vasconcelos em sua Falla dirigida a Assembleia Provincial, em outubro de 1859, informava um total de 19.000 declarações de terras, distribuídas pelas 57 freguesias. Em cinco anos - 1854 a 1859 - havia sido registrado um número importante, a despeito do discurso de dificuldades de diversas ordens.

No relatório do Ministério da Agricultura de 1860, no anexo da Repartição Geral das Terras Públicas, o diretor conselheiro Manoel Felizardo de Souza e Mello reiterou o problema do não envio dos registros paroquiais de terras por parte dos vigários. Mas, enfatizava que no Pará “as posses registradas elevão-se ao numero

apontar, da ótica do pesquisador, tanto para uma categoria fundamental ao discurso captado, quanto para um padrão de explicação. Suscitam uma determinada modalidade de pensar a situação da província cristalizada não só na produção erudita, mas também no pensamento político oficial" (ALMEIDA, 2008, p.65-66). Acredito que essa premissa auxilia também na reflexão do chamado fracasso da lei de terras de 1850.

25 PARÁ, Governo da província do. Falla dirigida á Assembléa Legislativa da provincia do Pará na segunda sessão da XI legislatura pelo exmo. sr. tenente coronel Manoel de Frias e Vasconcellos, presidente da mesma provincia, em 1 de outubro de 1859. Pará, Typ. Commercial de A.J.R. Guimarães, 1859. Disponível em: <http://www.crl.edu/content/provopen.htm> 
de $\mathbf{1 9 . 3 2 0}$ nos três prazos" ${ }^{26}$. Isso em 66 freguesias, dado que revela o crescimento da ação dos vigários, pois em relatório ministerial de 1858, a Repartição Especial das Terras Públicas do Pará havia recebido somente os Livros de Registros Paroquiais de 54 freguesias, e faltavam ainda sete, das quais os vigários foram instigados ${ }^{27}$ a enviarem os referidos Livros. Apenas cinco províncias prestaram informações deste quesito à Repartição Geral das Terras Públicas e a do Pará, entretanto, constava ser a Província possuidora do maior número de posses registradas.

Palma Muniz noticia a existência de 22.611 declarações de posse produzidas durante a execução do Decreto 1.318, que ele compilou dos livros de registros encaminhados pelos vigários e arquivados na Inspectoria de Terras e Obras Públicas. O trabalho de Palma Muniz é de $1907^{28}$.

Nesta pesquisa, ressalta-se que foi desencadeado um processo histórico com a Lei de Terras de 1850 e o Decreto de 1854 com impacto em nível das pequenas localidades, dos municípios e invólucro de diferentes agentes sociais (pequenos posseiros, grupos familiares e grandes posseiros) buscando regularizar as situações de terras que passariam para o controle particular. Talvez seja o primeiro movimento de mercado de terras ${ }^{29}$ provocado pela intervenção do Estado, e que significou uma grande transformação nas relações sociais.

Desta forma, consagrar que a lei foi um "fracasso" absoluto, sem atingir os objetivos, é desconsiderar a dinâmica da história, afirmando que no "fracasso", nada se cria de novo. Contrariamente esta lei visualizou os conflitos e diversas realidades etnográficas e históricas.

Para alguns, a Lei de Terras representou uma oportunidade de assegurar as suas porções de terras mediante o registro paroquial ${ }^{30}$.

26 BRASIL. Ministério da Agricultura. Ministro Manoel Felizardo de Souza e Mello. Relatório do Anno de 1860 apresentado a Assembléa Geral Legislativa na $1^{\mathrm{a}}$ Sessão da $11^{\mathrm{a}}$ Legislatura. Publicado em 1861. Disponível em: <http://brazil.crl.edu/bsd/bsd/u1733/>.

27 Ibidem.

28 Ibidem. Ver também: MUNIZ, 1907.

29 Entende-se por mercado de terra a efetiva mercantilização da terra. Ver Polanyi (2000) e Castro (1987).

30 Estudos recentes mostram a importância da lei para grupos socialmente constituídos e que se reconhecem como quilombolas. Na pesquisa cartorial no município de São Miguel do Guamá, foi levantada uma série de registros feitos no período de intensificação dos Registros Paroquiais por Raimundo Araújo Xavier. Estes documentos embasam a luta dos Quilombolas do município de Irituia, em Luta pelo Reconhecimento de Direitos Territoriais hoje. Para esta comunidade esses documentos "dos antigos", de seus antepassados, estava impresso, para além do direito costumeiro, e atestavam direitos à terra para as famílias daquele território. Na ilha de Marajó, no município de Cachoeira do Arari, encontrou-se a documentação em nome de Luis Antonio, de 1854, referente ao território hoje chamado "Terra Gurupá" - expressão utilizada pelos quilombolas do rio Arari 
A implementação da lei motivou situações novas, com a obrigatoriedade da declaração das terras revelou a pertinência de tentativa de normatização de uma prática social de acesso à terra, via a posse. Entre 1822 - data término do sistema sesmarial - até 1850, o império ficou sem um corpus lex que normatizasse a problemática da terra. O corpus que era utilizado era o Código Filipino, o qual, mesmo com a lei de terras de 1850, continuou sendo acessado nas disputas e pendências jurídicas envolvendo terras.

Dado revelador de outro aspecto do impacto da lei nos sujeitos que possuíam algum interesse e/ou vínculo com a questão fundiária é a desconfiança em relação à referida Lei de Terras, pois para alguns, havia o perigo de perderem as terras. Esse entendimento mereceu registro nas páginas de relatório ministerial, que apesar da tentativa de minimizar a importância, não deixou de mencionar como um dos fatores contributivos para a morosidade dos trabalhos de registro das terras possuídas.

Em relatório de 1855, o ministro Luiz Pedreira do Coutto Ferraz, no item Registro das Terras Possuídas, salientou que:

O registro das terras possuídas tem marchado com pouca actividade; porem só raramente, em uma ou outra localidade insignificante, tem apparecido reluctancia no cumprimento d'este dever, por entenderem erradamente alguns indivíduos nimiamente ignorantes, que podem perder as suas terras levando-as ao registro ${ }^{31}$.

A inquietação a ter resposta é: como, se era tão ínfimo o número de indivíduos (em tom depreciativo mencionando-os como "indivíduos nimiamente ignorantes") que achavam que podiam perder as suas terras, esse fato mereceu atenção especial no relatório ministerial? E isso logo no ano seguinte ao Decreto $n^{\circ} 1.318$, de 30 de janeiro de 1854, ou seja, há um estranhamento por parte dos possuidores de terras em relação à nova Lei. As informações, mesmo precariamente,

e rio Gurupá para legitimar o reconhecimento de seus direitos à referida terra. Esses documentos nas mãos de herdeiros, ciosamente guardados por significarem a "fala dos mortos que fala pelos vivos" - expressão manifesta do senhor Manoel Camilo Dias dos Santos, 74 anos, quilombola de "Terra Gurupá", revelam que os "antigos", no seu tempo, interpretaram o direito à área ocupada que lhes era garantido no corpo da Lei de Terras de 1850 e legislação posterior. Significa que eles procederam a interpretar as normas legais e os direitos de propriedade em seu tempo. Ver: "Quilombolas de Irituia (Pará) em Luta pelo Reconhecimento de Direitos Territoriais no Século XXI. Relatório Histórico-Antropológico de Identificação de Comunidades Remanescentes de Quilombos no Município de Irituia - Estado do Pará (Belém-Pará, junho/2008. Convênio INCRA/UNAMZ, Sob a coordenação da profa. Dra. Rosa Elizabeth Acevedo Marin - UFPA/ UNAMZ.

31 BRASIL. Ministério do Império. Relatorio do Anno de 1855 apresentado á Assembléa Geral Legislativa na quarta sessão da nona legislatura pelo ministro e secretario d'estado dos negócios do império Luiz Pedreira do Coutto Ferraz. Rio de Janeiro: Typographia Nacional, 1856. Disponível em: <http://brazil.crl.edu/bsd/bsd/ u1728/>. 
chegavam e inquietavam, mesmo no ápice do desenvolvimento dos trabalhos da Repartição das Terras Públicas.

Tratava-se apenas de "uma ou outra localidade", uma dessas em que as pessoas manifestaram seu estranhamento e desconfiança em relação à Lei foi a Vila de Cintra, na província do Pará. Em requerimento ${ }^{32}$ do ano de 1857, dirigido ao presidente da província, a senhora

Maria dos Prazeres, viúva de Germano Garcia, moradora no Rhio Caripi Districto da $V^{a}$ de Cintra, tendo sido multada por não apprezentar dentro do primeiro prazo a declaração das Terras em q habita, a Supp ${ }^{\mathrm{e}}$ não apprezentou a sua declaração $\mathrm{p}^{\circ}$ não saber como havia formular a $\mathrm{d}^{\mathrm{a}}$ declaração $\mathrm{p}^{\circ} \mathrm{q}^{\prime}$ suponha que devia apprezentar o Titulo das terras e como Ella não tem, nem sabe como as terras foram concedidas a seos Avós, só sabe q’ a mais de cincoenta ou sesenta annos, que seos Avós e Pais ali moravão, e agora a $\operatorname{Sup}^{a} \mathrm{p}^{\mathrm{o}}$ isso vem rogar a $\mathrm{V}^{\mathrm{a}} \mathrm{Ex}^{\mathrm{a}} \mathrm{Se}$ Digne Dispensa-la da multa, que não so p ignorância em que vivia, como pela como pela sua pobreza p q' pouco chega $\mathrm{p}^{\mathrm{a}}$ a sua sustentação e vestuário a que seos filhos trabalhão do q’ Arrogo de Maria dos Prazeres. Custódio Carlos da Silva

D. Maria requereu o perdão da multa a ela imputada, por não ter feito o registro de suas terras no primeiro prazo estipulado pelo governo, argumentando que não sabia - por desconhecimento mesmo - como fazer a declaração das terras em que morava. A Lei e suas disposições eram uma nova realidade jurídica para a maioria, e o medo ante a possibilidade de perder a terra se fazia presente, contrariando a afirmação do ministro Coutto Ferraz.

No referido requerimento, D. Maria expressa que além de não saber formular a declaração, acreditava que teria de apresentar o título das terras e "como Ella não tem, nem sabe como as terras foram concedidas a seos Avós, só sabe q' a mais de cincoenta ou sesenta annos, que seos Avós e Pais ali moravão”, optou por não registrar suas terras no Livro Paroquial do vigário.

Talvez as terras de dona Maria dos Prazeres respondiam pela situação jurídica de posse, e que, portanto, não tinha o título pertinente e se utilizou do fato de que ignorava como tinha sido a concessão, ou seja, não sabia como seus pais e avós por lá se fixaram, como adquiriram a terra - se por posse, compra, doação ou sesmaria. O fato de se reconhecer ignorante no trâmite de registrar as terras possuídas pode ter sido uma estratégia de D. Maria para burlar a obrigatoriedade do registro. Mas, precisamente, ela invocava um direito costumeiro ao afirmar que se não sabia a forma de concessão, D. Maria sabia que seus pais e avós moravam

32 O requerimento é assinado a rogo por Custódio Carlos da Silva, talvez ele tenha construído a argumentação de dona Maria dos Prazeres, mas por opção de escrita, imputamos a ela por ser a interessada direta. Arquivo Público do Pará. Fundo: Secretaria da Presidência da Província. Série: Requerimentos. Caixa 484. 1857. 
há mais de cinquenta ou sessenta anos. A outra possibilidade seria ela ter feito o registro nos prazos posteriores, já que solicitou o perdão da multa. Os argumentos utilizados no requerimento por D. Maria dos Prazeres acerca do pedido de perdão desencadeou uma rede de interpretações sobre a validade da Lei de 1850.

Mas a tensão em relação a esse pedido de perdão teve desdobramentos que, por meio de uma fresta, nos revelam um ângulo das tensões e dos conflitos experienciados pelos sujeitos no complexo processo de instituição da Lei de 1850 e as dificuldades gestadas no percurso. $\mathrm{O}$ despacho dado ao requerimento foi de que não havia lugar. O pedido de D. Maria dos Prazeres foi encaminhado pela secretaria do governo no dia 17 de junho de 1857 ao vigário da Vila de Cintra, para as devidas informações.

A manifestação do vigário coloca em xeque o alcance da Lei e o entendimento que alguns dos nimiamente ignorantes tiveram na Vila de Cintra. O vigário Thomaz d'Aquino Carreira afirmou que a argumentação de ignorância alegada por D. Maria dos Prazeres era falsa, e se ela não fez o registro das terras era por

Não querer ou por fazer pouco caso dos avizos que para isso teve, ou então por dar ouvidos a pessoas malévolas e intrigantes que não tendo meios para me desacreditarem com os meus parochianos, lhes tem dito que a Lei de Terras não é valiosa em parte alguma, e que só eu nesta Freguezia é que lhe quero dar valor e força, mas com o fim de comer o dinheiro dos pobres moradores desta Freguezia. Destas zisanias espalhadas aos moradores d'esta Freguezia

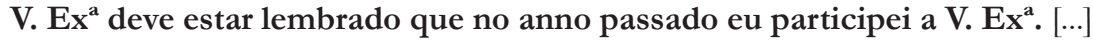
(grifo nosso) $^{33}$

O discurso do vigário expunha várias situações constrangedoras que partiam de ocorrências negativas aos "pobres moradores" como falcatruas, calhordices e enganos, dos que davam "ouvidos a pessoas malévolas e intrigantes", que os atingia duramente. Diante de tais experiências, o conhecimento da lei seguia percursos não imaginados e atingia um ritmo inesperado. Assim, não querer ou fazer pouco caso dos avisos, constituiu um posicionamento político, quem sabe até mesmo movido pela desconfiança, só que também havia as suposições de um agente imperial. Por outro lado, percebe-se uma circularidade das informações produzidas e como foram interpretadas, contribuindo para uma criticidade dos sujeitos contemplados na nova Lei.

A desconfiança que grassou em torno da lei era reforçada pela coerção

33 Arquivo Público do Pará. Fundo: Secretaria da Presidência. Série: Requerimentos. Caixa 484, 1857. 
institucional ditada pelas autoridades do império. As adjetivações expressadas pelo vigário - pessoas "malévolas e intrigantes" - revelam a marginalização ${ }^{34}$ daquelas pessoas vistas como discordantes do registro de terras. Para o Estado imperial, elas representavam um perigo à Lei. E esta, para os discordantes, também era entendida como perigosa, uma ameaça à conservação de suas posses, de suas terras.

Olhando ainda pela fresta do documento, infere-se que o referido vigário, um ano antes, havia notificado ao presidente acerca das atitudes e gestos de incredulidade de alguns moradores da Vila de Cintra acerca da Lei. Segundo esta autoridade religiosa e política, para os moradores, a "Lei de Terras não é valiosa em parte alguma". No exemplo de D. Maria dos Prazeres, seguiu as opiniões de pessoas "malévolas e intrigantes" que partilhavam dessa opinião.

Destaca-se uma circularidade política dos conflitos e as teias tecidas pelos sujeitos diretamente envolvidos no processo de identificação das situações fundiárias no Brasil. A resposta do vigário espelha uma rede de relações políticas cotidianas, que levaram algumas pessoas a tomarem a decisão de não registrarem as suas posses, contrariando frontalmente a perspectiva do governo imperial. Contudo, a multa prevista representava uma arma coercitiva à disposição do governo, pois quer se trate de uma sociedade simples ou uma complexa, a lei pode ser definida como autoridade escudada na força de sanções negativas (SHIRLEY, 1977).

Os "pequenos e nimiamente ignorantes" fizeram uma leitura possível da lei de acordo com o seu lugar social. Assim, não fazer o registro das terras possuídas, recorrer ao presidente da província pedindo o perdão da multa, informar ao presidente de que havia pessoas se recusando ou simplesmente ignorando os avisos e a normatização do Estado, são pontos da rede de conflitos gestados no cerne da implantação da Lei de Terras na província do Pará.

A historiografia geralmente entende que um dos pontos mais obscuros no processo de registros das terras era (e ainda é) a forma de aquisição, já que o declarante não era obrigado a informar de que maneira adquiriu a terra declarada. Essa brecha da lei permitia aos fazendeiros e lavradores que registrassem as

34 Ao analisar a Lei Negra, Thompson (1987, p. 245-296) reflete acerca da categoria "quadrilha", muitas vezes utilizada por historiadores atemporalmente, pois a categoria pode ser desumanizadora se for refletida descontextualizadamente, e aqueles que se contrapõem a uma normatização, podem ser vistos como uma ameaça à autoridade, à propriedade e à ordem. Sobre a Lei Negra, ele diz que "precisamos explicar não só uma emergência, mas uma emergência que agia sobre a sensibilidade desses homens", para quem a propriedade e o status privilegiado dos proprietários vinham assumindo, a cada ano, um maior peso nas escalas da justiça, até que a própria justiça não passava, aos seus olhos, das fortificações e defesas da propriedade e seu concomitante status. 
suas terras não se comprometerem em revelar no ato da declaração a forma de aquisição ${ }^{35}$. Mas, devido à desconfiança em torno da Lei de 1850, em alguns municípios do Pará encontramos situações diferentes.

As pessoas que se dirigiram ao pároco da freguesia de São Miguel do Guamá, para registrar as suas posses, informavam alguns dos dados solicitados. A obrigatoriedade de registrar a parcela de terra não vinha acompanhada da necessidade da comprovação documental ou testemunhal em relação à área efetivamente ocupada ${ }^{36}$. Entretanto, como o "declarante não era obrigado a informar de que maneira adquiriu a terra [...] é bastante comum a ausência desta informação nos registros paroquiais" ${ }^{37}$ em Paraíba do Sul, na província do Rio de Janeiro. Porém, para os fregueses de São Miguel, demonstrar documentalmente a forma de acesso à terra (por compra, doação, posse ou sesmaria) era fundamental para confrontar uma cultura jurídica com o Estado e a sua nova lei agrária. Assim, ao longo de sua narrativa enfatizavam possuir documentos longevos que comprovavam a forma de acesso à terra declarada, objetivando esclarecer e reafirmar o seu direito sobre ela. Ao fazer o registro de suas terras, em setembro de 1854,

Engracia Maria moradora no Igarapé Curiu no Rio Guamá Freguezia de Sam Miguel, em cumprimento ao Edital afixado pelo Reverendissimo Vigario da mesma, declara que possue no dito Rio um quarto de terras principiando dos marcos do Capitão Ignacio Feliz Guerreiro, rio acima lado esquerdo ate onde finalizar o dito quarto, cujas terras forão compradas por seu fallecido marido Marcos Joze de Campos a Dona Antonia Maria das Mercez em seis de Junho de mil oitocentos quarenta e dois como mostra pelas Escripturas publicas, que existem em seu poder, e cujas terras tem por nome $=$ Curiu $=$ por não saber ler nem escrever pedi ao abaixo assignado que este e igual traslado pr ella fizesse, e assignasse. Sam Miguel do Guamá desesete de Setembro de mil oitocentos cincoenta e quatro. Joaquim de Jezus e Castro ${ }^{38}$.

Para alguns declarantes seria fundamental, primeiro, cumprir a nova orientação do Estado imperial de proceder à declaração das terras possuídas. Em São Miguel do Guamá foi conhecido mediante o Edital afixado pelo Reverendo Vigário. O Art. 99 do Decreto n 1.318 explicitava que as instruções seriam dadas nas Missas Conventuais e "publicadas por todos os meios, que parecerem necessários para

35 Motta (1998, p.168-169).

36 Ibidem, p.166-167.

37 Ibidem, p.168-169.

38 PARÁ, Governo do Estado do. Instituto de Terras do Pará - Iterpa. Divisão de Documentação e Informação. Livro de Registro Paroquial de Terras. Freguesia da Vila São Miguel do Guamá, 189. 
o conhecimento dos respectivos freguezes" 39 . O Edital era um desses meios e foi afixado pelo respectivo Vigário da Freguesia de São Miguel do Guamá, e se infere que o vigário afixou-o em lugar visível na própria igreja. Segundo, a desconfiança em relação à nova lei fundiária levava a que muitos fizessem a leitura da nova orientação jurídica do governo confrontando-a com uma cultura jurídica ${ }^{40}$, onde o importante era demonstrar que havia uma anterioridade documental à Lei de Terras que lhes assegurava a posse da terra, ou seja, era fundamental convencer o governo de que as terras ali declaradas eram de origem legítima e juridicamente confirmada pelos documentos em poder dos declarantes e que isso não poderia ser alterado por uma nova legislação. Por isso, a ênfase das autoridades em informações uniformizadas para efeito de comprovação documental, à semelhança de "como mostra pelas Escripturas públicas, que existem em seu poder", reafirmadas pelo tempo da existência do documento ser anterior à lei, bem como pelo tempo de permanência na terra. Dona Engracia Maria acentuou que o seu falecido marido Marcos Joze de Campos, comprou as terras a Dona Antonia Maria das Mercez, em seis de setembro de mil oitocentos e quarenta e dois (1842).

Este argumento, com base em documentos, não parece raridade. Em 22 registros coletados, feitos por mulheres, 19 declarações enunciavam a existência de documentos em poder das declarantes. Tempo e documentação eram duas armas poderosas, habilmente utilizadas pelos fregueses de São Miguel do Guamá.

Entretanto, na falta de documentação comprobatória do acesso à terra, o recurso adotado era o da comprovação moral, havendo o confronto entre uma prática jurídica e o aspecto formal da lei de terras e as suas proposições, percebido nos fiambres de códigos e valores morais de um direito costumeiro. O costume, entendido enquanto legítimo e, portanto, com aceitação jurídica e força de lei, respaldava as pessoas que em situações limites perderam os documentos comprobatórios de acesso à terra e que argumentavam poder provar o seu direito e garantir o domínio por meio do testemunho de outrem.

Neste contexto, a testemunha deveria possuir idoneidade moral reconhecida publicamente, já que o seu depoimento tinha a aceitação e validade de prova; pois, na aceitação subjaziam critérios de valores como honestidade e comportamento

39 Decreto $\mathrm{N}^{\circ}$ 1.318, de 30 de Janeiro de 1854. Disponível em: <http:/ / extranet.agricultura.gov. $\mathrm{br} /$ sislegis-consulta $/$ consultarLegislacao.do?operacao $=$ visualizar\&id $=10515>$.

40 Para Shirley (1987, p. 43), "quase todas as sociedades têm alguma forma de cultura política, ou seja, uma opinião sobre o que é uma conduta apropriada e uma idéia de justiça”. É essa premissa de que os sujeitos possuem uma ideia de justiça que utilizaremos no presente trabalho. 
socialmente esperados, instituídos e submetidos às regras e padrões do meado do século XIX.

Foi assim com D. Custódia Maria, em setembro de 1854, que ao declarar a sua "sorte de terras no Sitio denominado Rosário, no Igarapé denominado do Tijuco”, afirmou que não poderia comprovar a herança recebida por parte de seu pai, por "não [existir] em seu poder titulo algum por ter sido consumido dos bixos com o decurso do tempo, pelo que protesta a declarante a tudo o tempo provar com testemunhas ser a supracitada sorte de terras suas [...]". ${ }^{41}$

Fazer a declaração em obediência ao Edital do Reverendo Vigário não significava aceitação inconteste do Registro. A desconfiança era subjacente ao ato de registrar; e se não se podia provar a forma de acesso e posse da terra com documentos escritos e juridicamente reconhecidos, utilizava-se práticas costumeiras, mas que não se creditasse aos registros o poder de questionar e/ou de determinar o sagrado direito sobre a terra.

Havia em torno dos Registros Paroquiais de Terra uma rede de tensões e interesses político-administrativos, pois o próprio ato de registrar a terra era imbuído de disposição e ação política efetiva do declarante em fazer ou não o registro.

As dificuldades eram muitas, conforme salientava o ministro da Repartição dos Negócios da Agricultura, Comércio e Obras Públicas, em relatório do ano de 1860, apresentado à Assembleia Geral Legislativa, no Rio de Janeiro. Uma das dificuldades enfatizada foi o fato de poucas províncias terem enviado o mapa solicitado pelo respectivo ministério, nos quais as informações deveriam ser "classificadas por comarcas, municípios e freguezias". Contudo, "poucas forão as províncias d'onde vierão taes mappas, e alguns incompletos" ${ }^{42}$. Outra dificuldade destacada foi a "notavel reluctancia, em que se têm conservado differentes vigários, não remettendo os livros de registros de suas parochias".

Das entrelinhas dessas observações, infere-se que a existência de tensões burocrático-administrativas entre as três esferas responsáveis pela condução do processo de separação das terras públicas das privadas: central - Rio de Janeiro, a provincial - Repartição Especial das Terras Públicas e os presidentes das províncias; e a local - atuação dos vigários nas suas freguesias.

41 PARÁ, Governo do Estado do. Instituto de Terras do Pará - Iterpa. Divisão de Documentação e Informação. Livro de Registro Paroquial de Terras. Freguesia da Vila São Miguel do Guamá. 42 BRASIL. Ministério da Agricultura. Ministro Manoel Felizardo de Souza e Mello. Relatório do Anno de 1860 apresentado a Assembléa Geral Legislativa na $1^{\text {a }}$ Sessão da $11^{\text {a }}$ Legislatura. Publicado em 1861. Disponível em: <http://brazil.crl.edu/bsd/bsd/ u1945/000001.gif>. 
Para o ministro Manoel Felizardo de Souza e Mello, a exceção foi o relatório apresentado pela Delegacia das Terras do Pará, que mereceu "especial menção" por "conter informações circumstanciadas e satisfactorias, [...] em um primeiro trabalho desta natureza"43.

Para Márcia Motta, os relatórios se contentavam em registrar o total das terras efetivamente declaradas, se havia ou não terrenos devolutos nos municípios, mas não procuravam descobrir as razões pelas quais os fazendeiros e lavradores se negavam a seguir a determinação legal (MOT'TA, 1998). Todavia, em muitos relatórios essa preocupação aparece como um grande empecilho ao avanço dos trabalhos pertinentes à Repartição Geral das Terras Públicas. Por outro lado, o governo pretendia acumular a maior quantidade possível de informações sobre a situação agrária do país - pelo menos no discurso... e, para isso, o Estado imperial precisava produzir os dados e os relatórios ministeriais constituem esse produto, mas, para isto, precisavam que as Repartições Especiais das Terras Públicas e os governos provinciais alimentassem-no, fornecendo os dados coletados nos diversos municípios do império.

Se durante os dois primeiros anos não se obteve grandes resultados nos primeiros relatórios ministeriais e provinciais, ao final dos anos 50 dos oitocentos, já se estruturava um quadro com alguns dados, mesmo que incipientes, e que escondiam os grandes problemas relacionados à terra na Província do Pará.

No relatório do ano de 1859 foram levantadas terras devolutas em algumas comarcas da Província do Pará (Quadro 2).

Quadro 2. Comarcas com terras devolutas.

\begin{tabular}{l|l}
\hline COMARCAS & \multicolumn{1}{c}{ MUNICÍPIOS } \\
\hline Capital & Vila de Igarapé-Miri, cidade da Vigia, vila de Curuçá e vila de Cintra \\
\hline Bragança e município & Vilas de Cachoeira, de Monsarás e de Chaves \\
\hline Marajó & Cametá e das vilas de Oeiras, de Breves e de Portel \\
\hline Cametá & Municípios do mesmo nome e de Porto de Moz \\
\hline Gurupá & $\begin{array}{l}\text { Macapá, da vila de Mazagão, da cidade de Santarém, das vilas de } \\
\text { Monte Alegre, de Alenquer, da Vila Franca, da cidade de Óbidos e } \\
\text { da vila de Faro }\end{array}$ \\
\hline Santarém &
\end{tabular}

Fonte: BRASIL. Ministério do Império. Ministro João de Almeida Pereira Filho. Relatório do anno de 1859 apresentado a Assembleia Geral legislativa na $4^{a}$ sessão da $10^{a}$ Legislatura.

43 BRASIL. Ministério da Agricultura. Ministro Manoel Felizardo de Souza e Mello. Relatório

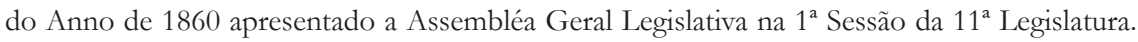
Publicado em 1861. Disponível em: <http://brazil.crl.edu/bsd/bsd/ u1945/000001.gif> 
No relatório de 1860, aparecem registradas 19.320 posses, em 66 freguesias. Mas, somente 26 posses foram legitimadas, sendo que 11 não foram "reformadas por ordem da presidência, por causa de irregularidades cometidas no processo e os funcionários foram condenados a restituir os emolumentos que nele intervieram"44. A corrupção foi um dos grandes problemas que perpassou os trabalhos da Repartição das Terras Públicas.

Partindo desses dados, mesmo que oficiais, seria arriscado afirmar que "Os resultados imediatos da Lei de Terras, no tocante à discriminação das terras estatais e sua venda, foram pouco expressivos" (SMITH, 1990, p.337).

Pareceria apologia de um pretenso sucesso da Lei de Terras, entretanto, é complicado se desconsiderar que o Estado obteve, mesmo que de forma embrionária e até pouco confiável, informações dos possuidores de terra, a sonegação e/ou imprecisão de informações por parte dos fazendeiros, a não delimitação e discriminação das terras públicas e privadas. Nenhuma dessas variáveis é questionada, mas, a partir dos registros, pode-se afirmar que se configurou um painel fundiário do país e o Estado buscou conferir as extensões existentes de terras devolutas no Brasil, mesmo que precariamente. Neste sentido, se os Registros Paroquiais de Terras, não possuíam uma função cadastral, "nem por isso deixavam de ter sensível importância como órgão de informação e de estatística" (LIMA, 1990. p.70).

Ainda no relatório supramencionado, o ministro afirmou que:

Não obstante, de quanto se tem exposto nos relatórios da repartição geral das terras publicas e do que passo a referi, ficara fora de duvida que muito errônea era a opinião, de que se havia formado a principio, de que no Brasil poucas terras devolutas poderião ser destinas à colonisação, por se acharem occupadas ou invadidas todas as que são mais vantajosamente situadas e offerecem melhores condições para o mencionado fim. ${ }^{45}$

Essa constatação de que "errônea era a opinião, de que se havia formado a principio, de que no Brasil poucas terras devolutas poderião ser destinas" para colonização é inquietante, e parece que foi ignorada pela historiografia. Com base nesse expediente, e apesar dos inúmeros obstáculos, a presente pesquisa revelou que dados primários foram coletados pela Repartição das Terras Públicas e com

44 BRASIL. Ministério do Império. Ministro João de Almeida Pereira Filho. Relatório do anno de 1860 apresentado a Assembléia Geral Legislativa. Disponível em: <http://brazil.crl. edu/bsd/ bsd/u1945/000101.html>.

45 BRASIL. Ministério da Agricultura. Ministro Manoel Felizardo de Souza e Mello. Relatório do Anno de 1860 apresentado a Assembléia Geral Legislativa. grifo nosso. 
todos os problemas presentes no cerne desses dados, eles permitiram a visualização de que o problema de terras no Brasil era muito mais complexo.

\section{REFERÊNCIAS}

ACEVEDO MARIN, R.; CASTRO, E. Negros do Trombetas - Guardiães de Matas e Rios. 2. ed. Belém: CEJUP, 1998.

ALMEIDA, A. W. B. de. A ideologia da decadência: uma leitura antropológica a uma história da agricultura do Maranhão. Rio de Janeiro: Casa 8; Fundação Universidade do Amazonas, 2008. p. 65-66.

AMAZONAS, Governo da província do. Exposição feita ao Exm $^{\circ} 1^{\circ}$ vicepresidente da província do Amazonas o Dr. Manoel Gomes Corrêa de Miranda, pelo Presidente, o Conselheiro Herculano Ferreira Penna, por occasião de passarlhe a administração da mesma província. Cidade da Barra, Typographia de Manoel da Silva Ramos, 11 de Março de 1855. p.14. Cf.: CENTER FOR RESEARCH LIBRARIES - CRL. Disponível em: <http://www.crl.edu/content/ provopen. htm>.

ARQUIVO Público do Pará. Fundo: Obras Públicas. Série: Diretoria Geral das Terras Públicas. n. 20. 1858.

ARQUIVO Público do Pará. Fundo: Repartição de Obras Públicas. Serie: Ofícios (Avisos) da Repartição Geral das Terras Públicas. v. 6. 1855-1857.

ARQUIVO Público do Pará. Fundo: Secretaria da Presidência da Província. Série: Requerimentos. Caixa 484. 1857.

BOURDIEU, P. O poder simbólico. 9. ed. Rio de Janeiro: Bertrand Brasil, 2006. p.217.

BRASIL. Ministério da Agricultura. Ministro Manoel Felizardo de Souza e Mello. Relatório do Anno de 1860 apresentado a Assembleia Geral Legislativa na $1^{\text {a }}$ Sessão da $11^{\text {a }}$ Legislatura. Publicado em 1861. Disponível em: < http://brazil.crl. $\mathrm{edu} / \mathrm{bsd} / \mathrm{bsd} / \mathrm{u1945/000001.gif>}$.

BRASIL. Ministério do Império. Ministro João de Almeida Pereira Filho. Relatório do anno de 1859 apresentado a Assembleia Geral legislativa na $4^{\mathrm{a}}$ sessão da $10^{\mathrm{a}}$ Legislatura. Cf.: CENTER FOR RESEARCH LIBRARIES - CRL. Disponível em: <HTTP://brazil.crl.edu/bsd/bsd/u1732/000001.html>. 
BRASIL. Ministério do Império. Ministro Sergio Teixeira de Macedo. Relatório

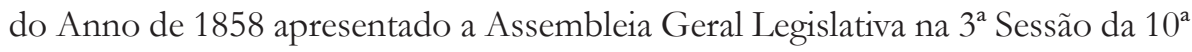
Legislatura. Publicado em 1959. Cf.: CENTER FOR RESEARCH LIBRARIES - CRL. Disponível em: <http://brazil.crl.edu/bsd/bsd/u1731/ 000001.html>.

BRASIL. Ministério do Império. Relatorio de 1856 apresentado à Assembleia Geral Legislativa na primeira sessão da décima legislatura pelo ministro e secretario d'estado dos negócios do império Luiz Pedreira do Coutto Ferraz. Rio de Janeiro: Typographia Nacional, 1857. p.12. Cf.: CENTER FOR RESEARCH LIBRARIES - CRL. Disponível em: <http://brazil.crl.edu/bsd/bsd/u325/index. html>.

BRASIL. Ministério do Império. Relatorio do Anno de 1855 apresentado à Assembleia Geral Legislativa na quarta sessão da nona legislatura pelo ministro e secretario d'estado dos negócios do império Luiz Pedreira do Coutto Ferraz. Rio de Janeiro: Typographia Nacional, 1856. Cf.: CENTER FOR RESEARCH LIBRARIES - CRL. Disponível em: < http://brazil.crl.edu/bsd/bsd/ u1728/>.

BRASIL. Ministério do Império. Relatório do Anno de 1855, apresentado na Assembleia Geral Legislativa, na $4^{\text {a }}$ Sessão da $9^{a}$ Legislatura. 1856. Cf.: CENTER FOR RESEARCH LIBRARIES - CRL. Disponível em: < http://brazil.crl. edu/ $\mathrm{bsd} / \mathrm{bsd} / \mathrm{u} 1728 / 000168 . \mathrm{html}>$.

CARVALHO, J. M. de. A construção da ordem: a elite política imperial - Teatro de sombras: a política imperial. 2. ed. Rio de Janeiro: Ed. UFRJ, Relume-Dumará, 1996. p. 303-225.

CARVALHO, J. M. de. A construção da ordem: a elite política imperial - Teatro de sombras: a política imperial. 2. ed. Rio de Janeiro: Ed. UFRJ, Relume-Dumará, 1996. p.155-80.

CASTRO, H. M. M. de. Ao sul da história. São Paulo: Brasiliense, 1987.

DECRETO 1.318, de 30 de janeiro de 1854. Capítulo I, Art. 2. Cf.: BRASIL. Ministério da Agricultura, Pecuária e Abastecimento. SISLEGIS - Sistema de Legislação Agrícola Federal. Disponível em: <http://extranet. agricultura.gov. $\mathrm{br} /$ sislegis-consulta $/$ consultarLegislacao.do?operacao $=$ visualizar $\& \mathrm{id}=10515>$.

DECRETO 1.318, de 30 de janeiro de 1854. Cf.: BRASIL. Ministério da Agricultura, Pecuária e Abastecimento. SISLEGIS - Sistema de Legislação Agrícola Federal. Disponível em: <http://extranet.agricultura.gov.br/ sislegis-consulta/ consultarLegislacao.do?operacao $=$ visualizar\&id $=10515$. 
FORTES, A. “O Direito na obra de E. P. Thompson”. Hitória Social. Campinas, n.2, 1995. Disponível em: < http:/ / www.ifch.unicamp.br/ojs/index.php/historia social/article/viewFile/191/168>.

JORNAL TREZE DE MAIO. n. 631. Belém, 8 de janeiro de 1856. p.2.

JORNAL TREZE DE MAIO. n. 632. Belém, 9 de janeiro de 1856. p.1.

JORNAL TREZE DE MAIO. n. 636. Belém, 14 de janeiro de 1856. p.2.

JORNAL TREZE DE MAIO. n. 651. Belém, 31 de janeiro de 1856. p.2.

JORNAL TREZE DE MAIO. n. 656. Belém, 7 de fevereiro de 1856. p.2.

LIMA, R. C. Pequena História Territorial do Brasil: sesmarias e terras devolutas. São Paulo: Secretaria de Estado de Cultura, 1990. p.70.

MARANHÃO, Governo da província do. Relatorio com que o vice presidente Jose Joaquim Texeira Vieira Berford, entregou a presidência da Província do Maranhão. O Illm. E Exm Snr. Commendador Antonio Candido da Cruz Machado. Maranhão, Typ. Const. de I. J. Ferreira. Cf.: CENTER FOR RESEARCH LIBRARIES - CRL. Disponível em: <http://brazil.crl.edu/bsd/bsd/u325/index. html>.

MOTTA, M. M. Direito à terra no Brasil - a gestação do conflito (1795-1824). São Paulo: Alameda, 2009.

MOTTA, M. M. Nas fronteiras do poder - conflito e direito à terra no Brasil do século XIX. Rio de Janeiro: Vício de Leitura, Arquivo Público do Estado do Rio de Janeiro, 1998.

MUNIZ, J. de P. Índice Geral dos Registros de Terras. Belém: Imprensa Oficial, 1907.

PARÁ, Governo da província do. Exposição apresentada pelo exmo. senr. conselheiro Sebastião do Rego Barros, presidente da provincia do Gram-Pará, ao exmo. Senr. tenente coronel d'engenheiros Henrique de Beaurepaire Rohan, no dia 29 de maio de 1856, por occasião de passar-lhe a administração da mesma provincia. Typ. de Santos e filhos, 1856. p.24-5. Cf.: CENTER FOR RESEARCH LIBRARIES - CRL. Disponível em: < http:/ / brazil. crl.edu/bsd/bsd/517/000024. html>. 
PARÁ, Governo da província do. Falla dirigida á Assembléa Legislativa da provincia do Pará na segunda sessão da XI legislatura pelo exmo. sr. tenente coronel Manoel de Frias e Vasconcellos, presidente da mesma provincia, em 1 de outubro de 1859. Pará, Typ. Commercial de A.J.R. Guimarães, 1859. Cf.: CENTER FOR RESEARCH LIBRARIES - CRL. Disponível em: <http://www.crl.edu/content/ provopen.htm>.

PARÁ, Governo da província do. Presidente (Rego Barros). Exposição de 14 de maio de 1855. p. 21. Cf.: CENTER FOR RESEARCH LIBRARIES - CRL. Disponível em: Disponível em: < http://brazil.crl.edu/bsd/bsd/u999/000023. html>.

PARÁ, Governo do Estado do. Instituto de Terras do Pará - Iterpa. Divisão de Documentação e Informação. Livro de Registro Paroquial de Terras. Freguesia da Vila São Miguel do Guamá, 189.

POLANYI, K. A grande Transformação: as origens de nossa época. Rio de Janeiro: Campus, 2000.

RAMA, A. A cidade das letras. São Paulo: Brasiliense, 1985.

SAMPAIO, P. M. “Vossa Excelência mandará o que for servido...’: políticas indígenas e indigenistas na Amazônia Portuguesa do final do século XVIII". Tempo. v. 12. n. 23. 2007. Disponível em: <http://www.scielo.br/scielo. php?pid $=$ S1413-77042007000200004\&script $=$ sci_abstract\&tlng $=$ pt $>$.

SHIRLEY, R. W. Antropologia Jurídica. São Paulo: Saraiva, 1987.

SHIRLEY, R. W. O fim de uma tradição. Cultura e desenvolvimento no município de Cunha. São Paulo: Perspectiva, 1977.

SILVA, L. O. da. Terras devolutas e latifúndio - Efeitos da Lei de 1850. Campinas: UNICAMP, 1996.

SISLEGIS - Sistema de Legislação Agrícola Federal. Disponível em: < http:// extranet.agricultura.gov.br/ sislegis-consulta/consultarLegislacao.do?operacao $=$ visualizar\&id $=10515>$.

SMITH, R. Propriedade da terra e transição - estudo da formação da propriedade privada da terra e a transição para o capitalismo no Brasil. São Paulo: Brasiliense, 1990. p. 337. 
THOMPSON, E. P. Senhores e Caçadores - a origem da lei negra. Rio de Janeiro: Paz e Terra, 1987.

TRINDADE, M. B. R. "Refluxos culturais da emigração portuguesa para o Brasil”. Análise Social. Vol.XXII. n. 90. 1986. p. 139-56. Disponível em: < http:/ / analisesocial.ics.ul.pt/documentos/ 1223483165U1cML5 by5Tp76UD3.pdf $>$.

Texo submetido à Revista em 20.4.2010

Aceito para publicação em 4.11.2010 